\title{
Erratum to: Interannual variations in primary and secondary growth of Nothofagus pumilio and their relationships with climate
}

\author{
Amaru Magnin · Javier Puntieri $\cdot$ Ricardo Villalba
}

Published online: 22 August 2014

(C) Springer-Verlag Berlin Heidelberg 2014

\section{Erratum to: Trees}

\section{DOI 10.1007/s00468-014-1049-3}

The original version of this article unfortunately contained a mistake. The expression representing "the year preceding a specified year" was misinterpreted and has been incorrectly replaced by "year ${ }^{-1}$ ". The correct expression should be "yr-1".

The online version of the original article can be found under doi:10.1007/s00468-014-1049-3.

A. Magnin $(\bowtie) \cdot$ J. Puntieri

INIBIOMA, CONICET-UNCOMAHUE, Quintral 1250,

8400 Bariloche, Argentina

e-mail: amagnin@comahue-conicet.gob.ar

J. Puntieri

Universidad Nacional de Río Negro, Sede Andina, El Bolsón,

Argentina

R. Villalba

IANIGLA, CCT-CONICET-Mendoza, C.C. 330, 5500 Mendoza,

Argentina 